\title{
Taxonomic characterization of Ketogulonigenium vulgare gen. nov., sp. nov. and Ketogulonigenium robustum sp. nov., which oxidize L-Sorbose to 2-keto-L-gulonic acid
}

\author{
1 Department of \\ Microbiology and \\ Molecular Genetics, \\ Michigan State University, \\ East Lansing, MI 48824- \\ 1101, USA \\ 2 Archer Daniels Midland \\ Company, Decatur, \\ IL 62526, USA
}

\author{
J. W. Urbance, ${ }^{1}$ B. J. Bratina, ${ }^{1}$ † S. F. Stoddard ${ }^{2}$ and T. M. Schmidt ${ }^{1}$ \\ Author for correspondence: T. M. Schmidt. Tel: +1 517353 1796. Fax: +1 5173538957. \\ e-mail: tschmidt@msu.edu
}

\begin{abstract}
Four bacterial strains that oxidize L-sorbose to 2-keto-L-gulonic acid, a key intermediate in the synthesis of vitamin $\mathrm{C}$, were isolated from soils of geographically distinct locations. All were Gram-negative, facultatively anaerobic, chemoheterotrophic rods. Comparative analysis revealed nearly identical 165 rDNA sequences amongst them (99.7-100\% identical) and identified them as members of the $\alpha$-subclass of the Proteobacteria. Phylogenetic analysis identified the closest taxonomically defined genus as Roseobacter (92.1-92.8\% identical). On the basis of phylogenetic, phenotypic and genotypic analyses, a new genus is proposed, Ketogulonigenium gen. nov. Based upon these analyses, we also propose the reclassification of strain DSM $4025^{\mathrm{TP}}$, originally identified as Gluconobacter oxydans, to the genus Ketogulonigenium. Two species are proposed: the type species Ketogulonigenium vulgare gen. nov., sp. nov., consisting of strains $62 \mathrm{~A}-12 \mathrm{~A}^{\mathrm{PP}}, 266-13 \mathrm{~B}^{\mathrm{PP}}$ and the type strain $K$. vulgare DSM $4025^{\mathrm{TP}}$, and Ketogulonigenium robustum gen. nov., sp. nov., consisting of the type strain $K$. robustum X6L ${ }^{\text {TP }}$ ( = NRRL B-21627 $=$ KCTC 0858BP). The species affiliation of the fifth strain (291-19P) remains unresolved.
\end{abstract}

Keywords: Ketogulonigenium, 2-keto-L-gulonic acid, ascorbic acid, vitamin C, Gluconobacter

\section{INTRODUCTION}

L-Ascorbic acid (vitamin C) can be synthesized chemically from D-glucose by the method of Reichstein \& Grussner (1934). This method involves many steps, and on a commercial scale requires large amounts of environmentally toxic solvents. Alternatively, the exploitation of micro-organisms to synthesize vitamin C or vitamin $\mathrm{C}$ precursors has both economic and ecological advantages. A number of axenic and mixedculture microbial processes have been described for the biosynthesis of various intermediates in L-ascorbic acid synthesis (Tengerdy, 1961a, b; Imai et al., 1990; Sugisawa et al., 1990; Yin et al., 1990; Nogami et al., 1995). One key intermediate in vitamin C synthesis is

\footnotetext{
†Present address: Department of Microbiology, University of Wisconsin - La Crosse, La Crosse, WI 54601, USA.

Abbreviation: 2-KLG, 2-keto-L-gulonic acid.

The GenBank accession numbers for the 165 rDNA sequences determined in this work are AF136846-AF136850.
}

2-keto-L-gulonic acid (2-KLG), which can be converted chemically to L-ascorbic acid by esterification followed by lactonization (Delic et al., 1989). Members of a number of bacterial genera have been identified that produce 2-KLG from the oxidation of L-sorbose (another intermediate of vitamin $\mathrm{C}$ synthesis). These include the acidophilic, $\alpha$-Proteobacteria Gluconobacter and Acetobacter, the $\gamma$-Proteobacteria Pseudomonas, Escherichia, Klebsiella, Serratia and Xanthomonas, the Gram-positive Bacillus and Micrococcus (Imai et al., 1990; Sugisawa et al., 1990; Yin et al., 1990; Nogami et al., 1995), and the genus 'Pseudogluconobacter' (Nogami et al., 1995). However, the yield of 2KLG from these organisms is generally too low to be exploited industrially (for a review of vitamin $\mathrm{C}$ chemistry, natural biosynthesis and industrial synthesis, see Delić et al., 1989).

To search for naturally occurring micro-organisms capable of more efficient conversion of L-sorbose to 2KLG, samples from a range of environments were used as inocula for media rich in L-sorbose. Those 
mixed-culture enrichments that demonstrated 2-KLG production were then screened for 2-KLG-producing isolates. We report here the polyphasic characterization of four isolates, representing a new, non-acidophilic genus of $\alpha$-Proteobacteria that is characterized by efficient production of 2-KLG from L-sorbose, Ketogulonigenium, and the reclassification of patent strain DSM $4025^{\mathrm{TP}}$, previously identified as Gluconobacter oxydans (Yin et al., 1990). Two species, Ketogulonigenium vulgare and Ketogulonigenium robustum, are proposed.

\section{METHODS}

Enrichment and isolation. Samples were taken of moist soil, sand, sediment, fruit, berries, humus and other environmental habitats from various regions of the midwestern, southern and southeastern United States. Following collection, each sample was immediately stored in a cool, ventilated and humidified container. For primary enrichment of L-sorbose-utilizing organisms, approximately $1 \mathrm{~g}$ of sample was added to $30 \mathrm{ml}$ Enrichment Medium A [EM-A; $20 \mathrm{~g}$ L-sorbose $1^{-1}, 2 \mathrm{~g}$ glucose $1^{-1}, 0 \cdot 1 \mathrm{~g} \mathrm{FeSO}_{4} \cdot 7 \mathrm{H}_{2} \mathrm{O} \mathrm{l}^{-1}$, $1.7 \mathrm{~g}$ Yeast Nitrogen Base (Difco) $1^{-1}, 6 \mathrm{~g} \mathrm{CaCO}_{3} \mathrm{l}^{-1}, 5 \mathrm{mg}$ cycloheximide $1^{-1}$ and $10 \mathrm{~g}$ corn steep liquor solids $1^{-1}$, pH 7.2] in a baffled $250 \mathrm{ml}$ flask and incubated with shaking (200-240 r.p.m.) for $2 \mathrm{~d}$ at $28-30{ }^{\circ} \mathrm{C}$. Secondary enrichments were established by using $0.50-0.75 \mathrm{ml}$ of the primary enrichments to inoculate $30 \mathrm{ml}$ of Enrichment Medium B (EM-B; same composition as EM-A except with $50 \mathrm{~g}$ L-sorbose $1^{-1}$ and no glucose). These were incubated as described above for 3-4 d, after which portions were analysed for 2-KLG production and cryogenically preserved. For cryogenic preservation, $2 \mathrm{ml}$ broth culture was added to $1 \mathrm{ml}$ sterile $40 \%(\mathrm{w} / \mathrm{v})$ glycerol and stored at $-70{ }^{\circ} \mathrm{C}$.

Culture media were screened for the presence of $2-\mathrm{KLG}$ using TLC on Whatman LK5 Silica Gel 150 plates $(0 \cdot 25 \mathrm{~mm}$ thick). The plates were spotted with $5 \mu$ l centrifuged broth culture and developed for 5-6 h in solvent $(157 \mathrm{ml} \mathrm{n-}$ propanol, $39 \mathrm{ml}$ deionized water, $4 \mathrm{ml} 1 \%$ (v/v) phosphoric acid and $0.4 \mathrm{ml}$ glacial acetic acid). The plates were air-dried, sprayed with a solution of tetrazolium blue chloride $(0 \cdot 125 \mathrm{~g}$ dissolved in $25 \mathrm{ml}$ methanol and $25 \mathrm{ml} 6 \mathrm{M} \mathrm{NaOH}$ ) and then baked at $60{ }^{\circ} \mathrm{C}$ for $5 \mathrm{~min}$. L-Sorbose and 2-KLG were visualized as purple spots on the finished plates and identified by comparison with a standard containing $10 \mathrm{~g} \mathrm{l}^{-1}$ each of L-sorbose and 2-KLG.

Production of 2-KLG was quantified by HPLC. Samples were prepared by $1: 10$ dilution in a solvent mobile phase $(1 \cdot 1 \mathrm{ml}$ ACS grade sulfuric acid diluted to $41 \mathrm{using}$ Milli-Q water), followed by filtration through a $0.45 \mu \mathrm{m}$ porous membrane. Samples of $100 \mu \mathrm{l}$ each were loaded onto two $2 \mathrm{~mm} \times 300 \mathrm{~mm} \times 7.8 \mathrm{~mm}$ Aminex HPX-87H columns (Bio$\mathrm{Rad}$ ) arranged in series to provide a total column length of $600 \mathrm{~mm}$, preceded by a guard column of the same resin. The column was run at $55^{\circ} \mathrm{C}$ at a flow rate of $0.6 \mathrm{ml} \mathrm{min}{ }^{-1}$. LSorbose and 2-KLG were detected using a Waters model no. 410 differential refractometer, and were identified by comparison with a standard containing 2-KLG and L-sorbose.

Mixed-culture enrichments that produced 2-KLG were then screened for 2-KLG-producing organisms. The frozen, glycerol stocks were serially diluted in EM-A and used to inoculate spread plates of EM-A agar. Plates were incubated at $30{ }^{\circ} \mathrm{C}$ for $24 \mathrm{~h}$ and colonies were picked after examination under $\times 8$ and $\times 40$ magnification. The plates were then incubated for an additional $24 \mathrm{~h}$ and re-examined for slower growing colonies. The individual colonies were transferred to EM-A agar for isolation. Several colonies of each type and size were subcultured. Each strain was further streaked for isolation one to three times on either EM-A or PYM plates $\left(10 \mathrm{~g}\right.$ peptone $\mathrm{1}^{-1}, 10 \mathrm{~g}$ yeast extract $\mathrm{l}^{-1}, 0.5 \mathrm{~g}$ glycerol $1^{-1}, 30 \mathrm{~g}$ mannitol $1^{-1}, 20 \mathrm{~g}$ agar $\left.1^{-1}\right)$. Pure cultures were then cryogenically preserved in PYM broth with $20 \%$ glycerol at $-70{ }^{\circ} \mathrm{C}$ and screened for their ability to convert L-sorbose to 2-KLG. To account for the possibility that 2-KLG production might require combined activity of two or more micro-organisms, each new isolate was tested in pairwise combination with all strains originating from the same enrichment, as well as in pure culture. Each strain or strain pair was grown in $30 \mathrm{ml}$ modified EM-B ( $15 \mathrm{~g}$ corn steep liquor solids $1^{-1}$, no cycloheximide) in $250 \mathrm{ml}$ shake flasks at $30{ }^{\circ} \mathrm{C}$ for $3 \mathrm{~d}$ and then screened for $2-\mathrm{KLG}$ production using TLC and HPLC as described above.

Maintenance media and growth conditions. The four new Ketogulonigenium isolates and strain DSM 4025 maintained on either Trypticase Soy Agar (TSA; Difco), Trypticase Soy Broth (TSB; Difco), or a complex medium [10 g Soytone (Difco) $1^{-1}, 10 \mathrm{~g}$ yeast extract $\mathrm{l}^{-1}, 20 \mathrm{~g}$ mannitol $1^{-1}, 5 \mathrm{~g} \mathrm{NaCl} \mathrm{l}^{-1}, 2 \cdot 5 \mathrm{~g} \mathrm{~K}_{2} \mathrm{HPO}_{4} \mathrm{1}^{-1}, 2 \%$ equine serum and $1.5 \%$ agar) designated here as SYM agar. Stock cultures were stored at $-80{ }^{\circ} \mathrm{C}$ in TSB supplemented with $25 \%$ glycerol. Roseobacter strains were maintained on Marine Agar 2216 (MA; Difco) or Marine Broth 2216 (MB; Difco) and stored at $-80{ }^{\circ} \mathrm{C}$ in $\mathrm{MB}$ supplemented with $25 \%$ glycerol.

Characterization of isolates was conducted using modifications of a defined basal medium designated here as DM (amounts are in $\mathrm{mg}^{-1}$ ) [yeast extract, 500; mannitol, 10000 ; 21 amino acids (includes hydroxyproline; 100 each), bases (adenine, uracil, guanine, thymine, cytosine; 100 each), $\mathrm{MgCl}_{2} .6 \mathrm{H}_{2} \mathrm{O}, 1000 ; \mathrm{NaSO}_{4}, 1000 ; \mathrm{NaCl}, 5000 ; \mathrm{KCl}, 350$; $\mathrm{K}_{2} \mathrm{HPO}_{4}, 140 ; \mathrm{CaCl}_{2} .2 \mathrm{H}_{2} \mathrm{O}, 75 ; \mathrm{NaBr}, 50 ; \mathrm{H}_{3} \mathrm{BO}_{3}, 20$; $\mathrm{Na}_{2} \mathrm{WO}_{4} \cdot 2 \mathrm{H}_{2} \mathrm{O}, 3$; nitrilotriacetate, $1 \cdot 5 ; \mathrm{FeSO}_{4} .7 \mathrm{H}_{2} \mathrm{O}$, $1.4 ; \mathrm{CuSO}_{4} .5 \mathrm{H}_{2} \mathrm{O}, 1 ; \mathrm{MnSO}_{4} \cdot \mathrm{H}_{2} \mathrm{O}, 0 \cdot 305 ; \mathrm{CoCl}_{2} \cdot 6 \mathrm{H}_{2} \mathrm{O}$, $0 \cdot 305 ; \mathrm{NiCl}_{2} \cdot 6 \mathrm{H}_{2} \mathrm{O}, 0 \cdot 20 ; \mathrm{Na}_{2} \mathrm{MoO}_{4} \cdot 2 \mathrm{H}_{2} \mathrm{O}, 0 \cdot 001$; pyridoxine. $\mathrm{HCl}, 0 \cdot 10$; $p$-aminobenzoic acid, $0 \cdot 05$; nicotinic acid, 0.05; DL-calcium pantothenate, 0.05; thiamin $\mathrm{HCl}$, 0.05; DL-6,8-thioctic acid, 0.05; riboflavin, 0.04; biotin, 0.02; folic acid, 0.02; vitamin $\mathrm{B}_{12}, 0.001 ; 250 \mathrm{mM}$ MOPS; $\mathrm{pH} 7 \cdot 2$, filter-sterilized) or TSB as described below. The ability to grow anaerobically was tested in $20 \mathrm{ml}$ serum vials containing $10 \mathrm{ml}$ anoxic TSB supplemented with $1 \mathrm{~g}$ glucose $1^{-1}$ (final glucose concentration was $19 \mathrm{mM}$ ). Motility was tested using an inoculating needle to stab plates of TSB containing $0.2 \%$ agarose. Unless otherwise stated, the $\mathrm{pH}$ of all media was $7 \cdot 2-7 \cdot 5$, all cultures were incubated at $28-30{ }^{\circ} \mathrm{C}$ and broth cultures were incubated on rotary shakers (200-250 r.p.m.). All characterizations were performed on cultures that were transferred no more than twice from frozen stocks.

The newly isolated strains have been deposited in the USDA Agricultural Research Service Culture Collection with the following accession numbers: NRRL B-21627 (strain X6L $\left.{ }^{\mathrm{TP}}\right)$, NRRL B-30035 (291-19 $\left.{ }^{\mathrm{PP}}\right)$, NRRL B-30036 $\left(266-13 B^{\mathrm{PP}}\right)$, NRRL B30037 (62A-12A $\left.{ }^{\mathrm{PP}}\right)$. Strain X6L ${ }^{\mathrm{TP}}$ was also deposited in the Korean Collection for Type Cultures under the accession number KCTC 0858BP. 


\section{Phenotypic characterization}

Colony and cell morphology. Colony morphology was evaluated after $48 \mathrm{~h}$ incubation on TSA. Cultures used for light microscopy were grown on either TSB or DM. For visualization of flagella, cells were harvested from motility plates by stabbing the edge of the zone of motile growth with a sterile Pasteur pipette and gently transferring the plug of agarose to a Formvar grid coated lightly with carbon. After 1-2 min, the agarose plug was wicked off from the side of the grid using filter paper and the grid was then negative-stained for $1 \mathrm{~min}$ with a solution of $1 \%(\mathrm{w} / \mathrm{v})$ phosphotungstic acid and $0.01 \%$ BSA (pH 6), after which the excess stain was also wicked off. Samples used for preparing thin sections were grown in TSB. Aliquots of the broth cultures were collected at 24 and $60 \mathrm{~h}$ and fixed by incubating them overnight in paraformaldehyde and glutaraldehyde [final concentration $2 \%(\mathrm{w} / \mathrm{v})$ each] at $4{ }^{\circ} \mathrm{C}$. The fixed cells were washed three times in fresh TSB, stained for $1 \mathrm{~h}$ at room temperature with TSB containing $1 \%(\mathrm{w} / \mathrm{v})$ osmium tetroxide, and then washed three times in double-distilled water. After centrifugation, the cell pellets were dehydrated in a graded ethanol series, washed three times with $100 \%$ acetone and infiltrated at room temperature with acetone/EPON resin (Embed 812, Electron Microscopy Sciences) mixtures. Thin sections were made using a Reichert Ultracut $\mathrm{S}$ ultramicrotome and counterstained with $10 \%(\mathrm{w} / \mathrm{v})$ uranyl acetate in methanol $(10 \mathrm{~min})$ followed by Sato's lead stain $(5 \mathrm{~min})$. Images were viewed and collected using a JEOL 1200EX scanning and transmission electron microscope (STEM).

Biochemical tests. Cytochrome oxidase was tested colorimetrically using a commercially available system (Dryslide; Difco) and catalase activity was tested for using $\mathrm{H}_{2} \mathrm{O}_{2}$ as described by Koneman et al. (1979).

Carbon sources. Carbon utilization was tested using a base medium of modified DM with reduced yeast extract $\left(0 \cdot 1 \mathrm{~g} \mathrm{l}^{-1}\right)$, amino acids $\left(0 \cdot 02 \mathrm{~g} \mathrm{l}^{-1}\right)$, bases $\left(0 \cdot 01 \mathrm{~g} \mathrm{l}^{-1}\right)$ and no mannitol. This medium supported growth of the isolates to very low cell yields. Carbon sources were added to the base medium at $20 \mathrm{~g} \mathrm{l}^{-1}$. Inocula for carbon utilization tests were grown overnight in the base medium. An aliquot $(100 \mu \mathrm{l})$ of these overnight cultures was used to inoculate tubes containing $6 \mathrm{ml}$ base medium plus a carbon source (each carbon source was tested in triplicate). Growth was monitored visually at regular intervals over $72 \mathrm{~h}$ and compared to growth in the base medium without added carbon source.

Temperature range and optima. Duplicate $250 \mathrm{ml}$ flasks with $50 \mathrm{ml} \mathrm{TSB}$ at the required growth temperature were inoculated with an overnight culture (grown in TSB) to a final $\mathrm{OD}_{600}$ of $0 \cdot 002-0 \cdot 007$. Growth of the isolates was monitored by measuring the $\mathrm{OD}_{600}$ in samples taken at regular intervals (1-4 h, depending on the growth rate) until the cultures reached stationary phase. Growth rate determinations were based upon a minimum of four OD measurements taken during exponential growth. Growth rates were determined at $4,10,15,25,28,30$ and $37^{\circ} \mathrm{C}$.

$\mathrm{pH}$ range and optima. Inocula for $\mathrm{pH}$ experiments were grown in unbuffered DM to mid-exponential phase. Aliquots of $125 \mu \mathrm{l}$ were used to inoculate duplicate test tubes containing $6 \mathrm{ml}$ DM buffered with either $250 \mathrm{mM}$ MES (pH 6.0-6.5) or $250 \mathrm{mM}$ MOPS (pH 6.5-8.5). The range of pHs tested was $6.0-8.5$ at intervals of $0.25 \mathrm{pH}$ units, and $\mathrm{pH} 4 \cdot 5$. Growth was monitored visually at regular intervals over $72 \mathrm{~h}$.

Salt tolerance. Inocula for salt tolerance experiments were grown to mid-exponential phase in modified DM $(0 \%$ added $\mathrm{NaCl}$, unbuffered). Aliquots of $125 \mu \mathrm{l}$ were used for inoculation. Salt tolerance was tested in duplicate test tubes containing $6 \mathrm{ml}$ DM with the following modifications: $\mathrm{NaCl}$ concentration was varied from 0 to $4 \%$ at $0.5 \%$ intervals and the MOPS concentration was reduced to $25 \mathrm{mM}$ to reduce the $\mathrm{Na}^{+}$concentration of the basal medium to $31.2 \mathrm{mM}$. $\mathrm{OD}_{600}$ was measured at regular intervals using a Spec20 (Milton Roy).

BIOLOG metabolic experiments. Each isolate was grown in $20 \mathrm{ml} \mathrm{TSB}$ to an $\mathrm{OD}_{600}$ of 1.0 or greater. The cells were harvested by centrifugation at $10000 \mathrm{~g}$ and resuspended in $20 \mathrm{ml}$ unbuffered saline $(0 \cdot 85 \% \mathrm{NaCl})$. BIOLOG GN MicroPlates were inoculated using $150 \mu \mathrm{l}$ of the cell suspension per well. Plates were sealed with Parafilm and incubated at $30^{\circ} \mathrm{C}$. Metabolic activity in the wells was measured as a change in $\mathrm{OD}_{590}$ using a EL $312 \mathrm{e}$ microplate reader (Bio-Tek Industries). Measurements were taken immediately after inoculating the wells and approximately 2 , 4 and $6 \mathrm{~h}$ following inoculation. The capacity for substrate oxidation was scored based on optical density readings after $6 \mathrm{~h}$. The results were scored as negative $\left(\mathrm{OD}_{590} 0-0 \cdot 1\right)$, weakly positive $\left(\mathrm{OD}_{590} 0 \cdot 1-0 \cdot 5\right)$ or positive $\left(\mathrm{OD}_{590}>0 \cdot 5\right)$.

Cellular fatty acids. Fatty acid profiles were quantified and identified by comparison to a commercial database, the Sherlock Microbial Identification System (MIS) by Microbial ID (MIDI) using the manufacturer's protocols. Isolate identifications were attempted by comparison to the MIDI TSBA (version 3.9) microbial database. The isolates were compared to the library using covariance matrix, principal component analysis and pattern recognition software.

MIC testing. The MICs of selected antibiotics were determined using a microbroth dilution technique in accordance with the procedure described in the National Committee for Clinical Laboratory Standards (NCCLS) M31-T document. This procedure involved using a commercially available microtitre tray (Pasco Laboratories). Escherichia coli ATCC 25922 and Staphylococcus aureus ATCC 29213 were used as standards for quality control. The microtitre trays were incubated at $22^{\circ} \mathrm{C}$ for $24-48 \mathrm{~h}$. The MIC for each drug/bacterium combination was recorded as the lowest concentration of the drug that completely inhibited the growth of the bacterial isolates as determined visually. In some cases, antibiotics were tested in combination to reflect common clinical usage.

\section{Genotypic characterization}

DNA preparation. Cells harvested from TSB cultures were suspended in $10 \mathrm{ml} \mathrm{TE}, \mathrm{pH} 8$ (Sambrook et al., 1989a) containing $0.5 \%$ SDS and $0 \cdot 1 \mathrm{mg}$ proteinase $\mathrm{K}^{-1}$, and lysed by incubation at $37^{\circ} \mathrm{C}$ for $1 \mathrm{~h}$. Nucleic acids were purified by three extractions with TE-saturated phenol $(\mathrm{pH} 7)$, three extractions with TE-saturated phenol/chloroform/isoamyl alcohol (25:24:1, by vol.) and two extractions with chloroform, followed by ethanol precipitation. Nucleic acid precipitates were twice washed with $80 \%$ ethanol and redissolved in TE $\mathrm{pH}$ 8. Chromosomal and plasmid DNAs were further purified and separated by centrifugation in $\mathrm{CsCl}$ gradients (Sambrook et al., 1989b). After harvesting the DNA bands from the gradients, excess ethidium bromide was removed by repeated water-saturated butanol extraction and the final DNA preparations purified using Centricon 30 columns (Amicon) as per the manufacturer's recommendations. The concentration and purity of DNA samples were quantified spectrophotometrically. Agarose gel electro- 
phoresis $(0.8 \%$ agarose in $1 \times$ TAE $)$ was also used to assess the quality of the DNA preparations and for the visualization of plasmids.

$\mathrm{G}+\mathrm{C}$ content. This was determined by the thermal denaturation $\left(T_{\mathrm{m}}\right)$ method of Marmer \& Doty (1962) using a PerkinElmer Lambda 14 spectrophotometer with a water-jacketed cuvette holder connected to a circulating waterbath. The correlation between cuvette and waterbath temperatures was previously established using a thermister in a sealed cuvette. Approximately $50 \mu \mathrm{g}$ genomic DNA in $1 \mathrm{ml} 0.5 \times$ SSC was used for analysis. Because the $\mathrm{G}+\mathrm{C}$ content of the chromosomal DNA from Spirochaeta aurantia strain $\mathrm{J} 1^{\mathrm{T}}$ has been previously determined by the same method (Breznak \& Canale-Parola, 1975), it was used as a reference to verify the system. The genomic denaturation temperature $\left(T_{\mathrm{m}}\right)$ determined by this analysis was subsequently used to calculate the hybridization temperature used in the DNA-DNA hybridization studies (below).

DNA-DNA hybridization. Genomic DNA similarities were determined by a membrane hybridization method. DNA was immobilized on nylon membrane (MSI) using a slotblot device (ABN VacuSystems; American Bionetics) to membrane saturation. Membrane saturation was empirically determined to be 4-5 $\mu \mathrm{g}$ per slot. Genomic DNAs were sheared by 20 passages through a 30 gauge needle, denatured for $10 \mathrm{~min}$ at room temperature in $0.4 \mathrm{M} \mathrm{NaOH}$ and then diluted in 9 vols $6.7 \times \mathrm{SSC}$ (final concentration $6 \times \mathrm{SSC}$ ). Five micrograms of DNA were then deposited per slot. DNA was fixed to the membrane by UV cross-linking $(1200 \mathrm{~mJ})$ followed by baking at $80^{\circ} \mathrm{C}$ for $2 \mathrm{~h}$. Membranes were prehybridized in $8 \mathrm{ml}$ hybridization buffer $[0.9 \mathrm{M} \mathrm{NaCl}$, $0.15 \mathrm{M}$ Tris, $5 \mathrm{mM}$ EDTA, 0.5\% SDS, $100 \mathrm{mg}$ Poly(A) $\mathrm{ml}^{-1}, 5 \times$ Denhardt's solution (Sambrook et al., 1989c), $\mathrm{pH} 7 \cdot 5$ ] for $5 \mathrm{~h}$ at $68^{\circ} \mathrm{C}\left(T_{\mathrm{m}}=25^{\circ} \mathrm{C}\right)$. This was replaced with $3 \mathrm{ml}$ fresh hybridization buffer and $1 \mu \mathrm{g}{ }^{32} \mathrm{P}$-labelled probe was added. Sheared genomic DNAs were used to make nicktranslated probes using a commercial kit (Gibco BRL) as per the manufacturer's instructions. Hybridizations were incubated for $18-24 \mathrm{~h}$ at $68^{\circ} \mathrm{C}$. Hybridized membranes were briefly rinsed twice with $80 \mathrm{ml}$ wash solution $(\mathrm{WS} ; 1 \times \mathrm{SSC}$, $1 \% \mathrm{SDS}$ ) and washed for $30 \mathrm{~min}$ at room temperature in $80 \mathrm{ml}$ fresh WS. Membranes were then stringently washed for $15 \mathrm{~min}$ at $68^{\circ} \mathrm{C}$ in $80 \mathrm{ml} \mathrm{WS}$, transferred to $80 \mathrm{ml}$ of fresh WS and washed for an additional $15 \mathrm{~min}$ at $68^{\circ} \mathrm{C}$. Membranes were finally washed overnight at room temperature in $200 \mathrm{ml} \mathrm{WS}$ to remove excess background counts. The specifically bound probe was quantified using a radioanalytic imaging system (AMBIS)

Phylogenetic analysis. The 16S-rRNA-encoding genes (rDNA) were amplified by PCR from genomic DNA using oligonucleotide primers designed to anneal to conserved regions of bacterial small subunit rDNA. The forward primer corresponded to positions 8-27 of E. coli $16 \mathrm{~S}$ rRNA, while the reverse primer corresponded to positions 1492-1510 (Eden et al., 1991). Reaction conditions and cycling profiles were as described by Eden et al. (1991). The amplified product was purified using Millipore MWCO columns (Ultrafree-MC) as per the manufacturer's recommendation. Cycle sequencing was performed on a Perkin Elmer 9600 thermal cycler using ABI dye terminator chemistry (PE Applied Biosystems) and products were analysed on an ABI 373a DNA sequencer. A collection of 12 primers (MicroSeq 16SrRNA Gene kit; PE Applied Biosystems) was used for sequencing, which provided an average redundancy of 3.0 per nucleotide position. Consensus sequences generated from assembled contigs were used for analysis. Sequences generated in the present study were deposited in GenBank (accession numbers AF136846AF136850).

The consensus sequences were aligned against the most similar sequences in the ARB small subunit rRNA database using the alignment algorithm in ARB (www.mikro. biologie.tu-muenchen.de). Additional 16S rRNA sequences from closely related bacteria were retrieved from GenBank following a BLAST search (Altshul et al., 1990). Sequence alignments were adjusted manually based upon elements of primary sequence and secondary structure. Ultimately, phylogenetic analysis was based on 1197 nucleotide positions that were present in all sequences compared and unambiguously aligned. Phylogenetic analyses were performed by the neighbour-joining (Saitou \& Nei, 1987) and distance (DeSoete, 1983) methods from within the ARB environment and by a maximum-likelihood method using the program fastDNAml (Olsen et al., 1994). Bootstrap values were based on 100 trees generated using the program fastDNAml_boot.

\section{RESULTS}

\section{Enrichment and isolation}

Approximately 270 environmental samples were screened as described above. Thirty-three of these enrichments produced 2-KLG in amounts ranging from 1.8 to $9 \cdot 3 \mathrm{~g} \mathrm{l}^{-1}$. Of those, only the $11 \mathrm{most}$ productive enrichments were screened for 2-KLGproducing isolates. Each enrichment yielded 4-15 isolates, which were then screened individually and in pairwise combinations for their ability to convert Lsorbose to $2-\mathrm{KLG}$ (a total of 118 isolates). Appreciable $\left(>3 \mathrm{~g}^{-1}\right)$ 2-KLG production was demonstrated in 4 of the 118 isolates (each from a different sample). The four isolates also came from geographically distinct locations: $266-13 \mathrm{~B}^{\mathrm{PP}}$ and $291-19^{\mathrm{PP}}$ were isolated from different samples taken from around a sugar refinery in Louisiana, $62 \mathrm{~A}-12 \mathrm{~A}^{\mathrm{PP}}$ was isolated from forest soil in western Tennessee and $\mathrm{X} 6 \mathrm{~L}^{\mathrm{TP}}$ was isolated from cotton field soil in Alabama. Also included in the present study was DSM $4025^{\mathrm{TP}}$, a patent strain originally deposited at the Deutsche Sammlung von Mikroorganismen (DSM) as Gluconobacter oxydans (Yin et al., 1990).

\section{Morphology}

Strains $\mathrm{X} 6 \mathrm{~L}^{\mathrm{TP}}$ and $\mathrm{DSM} 4025^{\mathrm{TP}}$ formed visible, pinpoint colonies $24-36 \mathrm{~h}$ after incubation at $30^{\circ} \mathrm{C}$ on TSA. Strains $266-13 \mathrm{~B}^{\mathrm{PP}}, 291-19^{\mathrm{PP}}$ and $62 \mathrm{~A}-12 \mathrm{~A}^{\mathrm{PP}}$ usually required $48 \mathrm{~h}$ incubation before colonies were visible. Older cultures of all strains produced tancoloured, smooth, circular, entire, raised to convex colonies that were $1-2 \mathrm{~mm}$ in diameter. In broth culture, $62 \mathrm{~A}-12 \mathrm{~A}^{\mathrm{PP}}$ differed from the other strains in producing a flocculent turbidity. A brown, diffusible, water-soluble pigment with a single absorbance maximum of $310 \mathrm{~nm}$ was visible in the agar around colonies after 3-4 d incubation and in broth cultures after 1-2 d. Pigment production was $\mathrm{pH}$-dependent. The amount of pigment produced increased with increasing 
Table 1. Phenotypic characteristics of Ketogulonigenium strains and selected relatives

Except where noted, data for Roseobacter, Gluconobacter and Acetobacter are based upon published results (Shiba, 1991, 1992; Lafay et al., 1995; Ruiz-Ponte et al., 1998; De Ley et al., 1984; De Ley \& Swings, 1984). ND, No data; d, inconclusive results; w, weak reaction; $v$, variable results.

\begin{tabular}{|c|c|c|c|c|c|c|c|c|}
\hline \multirow[t]{2}{*}{ Characteristic } & \multicolumn{8}{|c|}{ Strain/species } \\
\hline & DSM $4025^{\mathrm{TP}}$ & $62 \mathrm{~A}-12 \mathrm{~A}^{\mathrm{PP}}$ & 266-13B ${ }^{P P}$ & $291-19^{\mathrm{PP}}$ & $\mathrm{X}_{6} \mathrm{~L}^{\mathrm{TP}}$ & Roseobacter & Gluconobacter & Acetobacter \\
\hline Cell shape & Ovoid to rods & Ovoid to rods & Ovoid to rods & Ovoid to rods & Ovoid to rods & Ellipsoidal to rods & Ovoid to rods & $\begin{array}{l}\text { Ellipsoidal to straight to } \\
\text { curved rods }\end{array}$ \\
\hline \multicolumn{9}{|l|}{ Cell size $(\mu \mathrm{m})$ : } \\
\hline Length & $0 \cdot 8-1 \cdot 0 *$ & $1 \cdot 0-1 \cdot 1^{*}$ & $0 \cdot 9-1 \cdot 1^{*}$ & $0 \cdot 8-1 \cdot 3^{*}$ & $0 \cdot 8-1 \cdot 0^{*}$ & $1 \cdot 0-2 \cdot 0$ & $0 \cdot 9-4 \cdot 2$ & $1 \cdot 0-4 \cdot 0$ \\
\hline Diameter & $0 \cdot 5-0 \cdot 7^{*}$ & $0 \cdot 5-0 \cdot 7^{*}$ & $0 \cdot 6-0 \cdot 7^{*}$ & $0 \cdot 6-0 \cdot 7^{*}$ & $0 \cdot 6-0 \cdot 7^{*}$ & $0 \cdot 6-0 \cdot 9$ & $0 \cdot 5-0 \cdot 8$ & $0 \cdot 6-0 \cdot 8$ \\
\hline Anaerobic growth & + & + & + & + & + & - & - & - \\
\hline Non-diffusible pigment & - & - & - & - & - & Pink-red & $\mathrm{v}$ & $\mathrm{v}$ \\
\hline Diffusible pigment & Brown & Brown & Brown & Brown & Brown $\dagger$ & - & $\mathrm{v}$ & $\mathrm{v}$ \\
\hline Oxidase & + & + & + & + & + & + & - & - \\
\hline Catalase & + & + & + & + & + & + & + & + \\
\hline Motility & - & $-\ddagger$ & - & - & + & + & V & v \\
\hline Optimum temperature range $\left({ }^{\circ} \mathrm{C}\right)$ & $27-29$ & $28-30$ & $28-30$ & $25-28$ & $29-31$ & $20-30$ & $25-30$ & $25-30$ \\
\hline Growth at $4{ }^{\circ} \mathrm{C}$ & - & + & + & + & - & $\mathrm{v}$ & ND & ND \\
\hline Growth at $37^{\circ} \mathrm{C}$ & - & - & - & - & + & - & - & $\mathrm{v}$ \\
\hline Optimum $\mathrm{pH}$ range & $7 \cdot 5-8 \cdot 0$ & $7 \cdot 2-7 \cdot 7$ & $7 \cdot 5-7 \cdot 7$ & $7 \cdot 2-8 \cdot 0$ & $8 \cdot 0-8 \cdot 5$ & $7 \cdot 0-8 \cdot 0$ & $5 \cdot 5-6 \cdot 0$ & $5 \cdot 4-6 \cdot 3$ \\
\hline Growth at $\mathrm{pH} 4.5$ & - & - & - & - & - & - & + & + \\
\hline Optimum $\left[\mathrm{Na}^{+}\right](\mathrm{mM})$ & $31 \cdot 2 \S$ & $31 \cdot 2 \S$ & $31 \cdot 2 \S$ & $31 \cdot 2 \S$ & $117-459$ & ND & ND & ND \\
\hline Growth in $4 \%(w / v) ~ N a C l$ & + & + & + & + & + & ND & ND & ND \\
\hline \multicolumn{9}{|l|}{ Carbon sources:\| } \\
\hline Fructose & + & - & $+(w)$ & $d(w)$ & + & ND & ND & ND \\
\hline Raffinose & - & $-(w)$ & $-(w)$ & $\mathrm{d}$ & - & ND & ND & ND \\
\hline Sucrose & $+(-)$ & $-(\mathrm{w})$ & $+(-)$ & $+(\mathrm{w})$ & $+(-)$ & ND & ND & ND \\
\hline Trehalose & + & - & + & + & + & ND & ND & ND \\
\hline Pyruvate & + & $\mathrm{d}$ & d & $\mathrm{d}$ & + & ND & ND & ND \\
\hline Succinate & $+(-)$ & - & $+(-)$ & $\mathrm{d}(-)$ & $+(-)$ & ND & $\mathrm{ND}$ & $\mathrm{ND}$ \\
\hline \multicolumn{9}{|l|}{ Antibiotic MICs: $\left(\mu \mathrm{g} \mathrm{ml}^{-1}\right)$} \\
\hline Florfenicol & $1 \cdot 0$ & $1 \cdot 0$ & $0 \cdot 5$ & $0 \cdot 5$ & $1 \cdot 0$ & ND & ND & ND \\
\hline Gentamicin & $0 \cdot 12$ & $0 \cdot 12$ & $0 \cdot 12$ & $0 \cdot 25$ & $0 \cdot 12$ & ND & ND & ND \\
\hline Sarafloxacin & $0 \cdot 06$ & $0 \cdot 06$ & $0 \cdot 06$ & $0 \cdot 06$ & $0 \cdot 12$ & ND & $\mathrm{ND}$ & ND \\
\hline Tilmycosin & $8 \cdot 0$ & $4 \cdot 0$ & $4 \cdot 0$ & $4 \cdot 0$ & $2 \cdot 0$ & ND & $\mathrm{ND}$ & $\mathrm{ND}$ \\
\hline $\mathrm{G}+\mathrm{C}$ content $(\mathrm{mol} \%)$ & $54 \cdot 0$ & $54 \cdot 0$ & $53 \cdot 6$ & $53 \cdot 4$ & $52 \cdot 1$ & $56 \cdot 3-59 \cdot 6$ & $56-64$ & $51-65$ \\
\hline Plasmids present & - & - & - & $+\#$ & $+\#$ & $-* *$ & ND & ND \\
\hline
\end{tabular}

* Growth in DM broth.

$\dagger$ Production of pigment weaker and more variable than with the other Ketogulonigenium strains.

\$ Motility demonstrated in one instance (see text).

$\S$ Lowest $\mathrm{Na}^{+}$concentration tested $\left(\mathrm{Na}^{+}\right.$concentration of $\mathrm{DM}$ with no added $\left.\mathrm{NaCl}\right)$.

$\|$ Data shown only for those substances that differed between strains; see text for further information. Data are shown for both conventional and BIOLOG methods; BIOLOG data are shown in parentheses when they differed from those for conventional methods.

- Data shown only for those substances that differed between strains; see text for further information.

\# Strain 291-19 ${ }^{\mathrm{PP}}$ contained one 8-9 kb plasmid; strain X6L $\mathrm{L}^{\mathrm{TP}}$ contained multiple plasmids.

** Data based upon present study.

initial $\mathrm{pH}$ of the medium up to approximately $\mathrm{pH} 7 \cdot 2$, above which pigment production was more uniform. Little or no pigment was produced when the starting $\mathrm{pH}$ of the medium was below 6.75 or in unbuffered media (starting $\mathrm{pH} 7 \cdot 2-7 \cdot 3$ ) containing carbon sources which resulted in significant acid production (e.g. glucose). Pigment production of strain $\mathrm{X} 6 \mathrm{~L}^{\mathrm{TP}}$ was weaker and more variable than that of the other strains. When grown on inositol, all strains produced a bright yellow compound and no brown pigment was observed.

The cell morphology of all strains was similar when grown in DM broth (Table 1). However, there were considerable differences in morphology between strains when grown on TSB (Fig. 1c). While X6L $\mathrm{L}^{\mathrm{TP}}$ looked similar in both media, in the TSB medium cells of strains DSM $4025^{\mathrm{TP}}$ and $62 \mathrm{~A}-12 \mathrm{~A}^{\mathrm{PP}}$ were somewhat longer $(2-3 \mu \mathrm{m})$ while cultures of strain $266-13 \mathrm{~B}^{\mathrm{PP}}$ and $291-19^{\mathrm{PP}}$ contained mostly elongated, odd-shaped cells, $7-30 \mu \mathrm{m}$ in length after $24-36 \mathrm{~h}$. Also, the development of chains of cells by all the strains was more common in TSB than in DM. Fig. 1(a) is a negatively stained electron micrograph of $\mathrm{X} 6 \mathrm{~L}^{\mathrm{TP}}$ illustrating the presence of flagella. Fimbrae were observed in TEM micrographs of thin sections of X6L ${ }^{\mathrm{TP}}$ and $291-19^{\mathrm{PP}}$ (Fig. 1b). TEM of thin sections was not performed on the other strains. All strains were Gram-negative, although $\mathrm{X} 6 \mathrm{~L}^{\mathrm{TP}}$ differed from the other strains in a tendency to resist decolorization. 

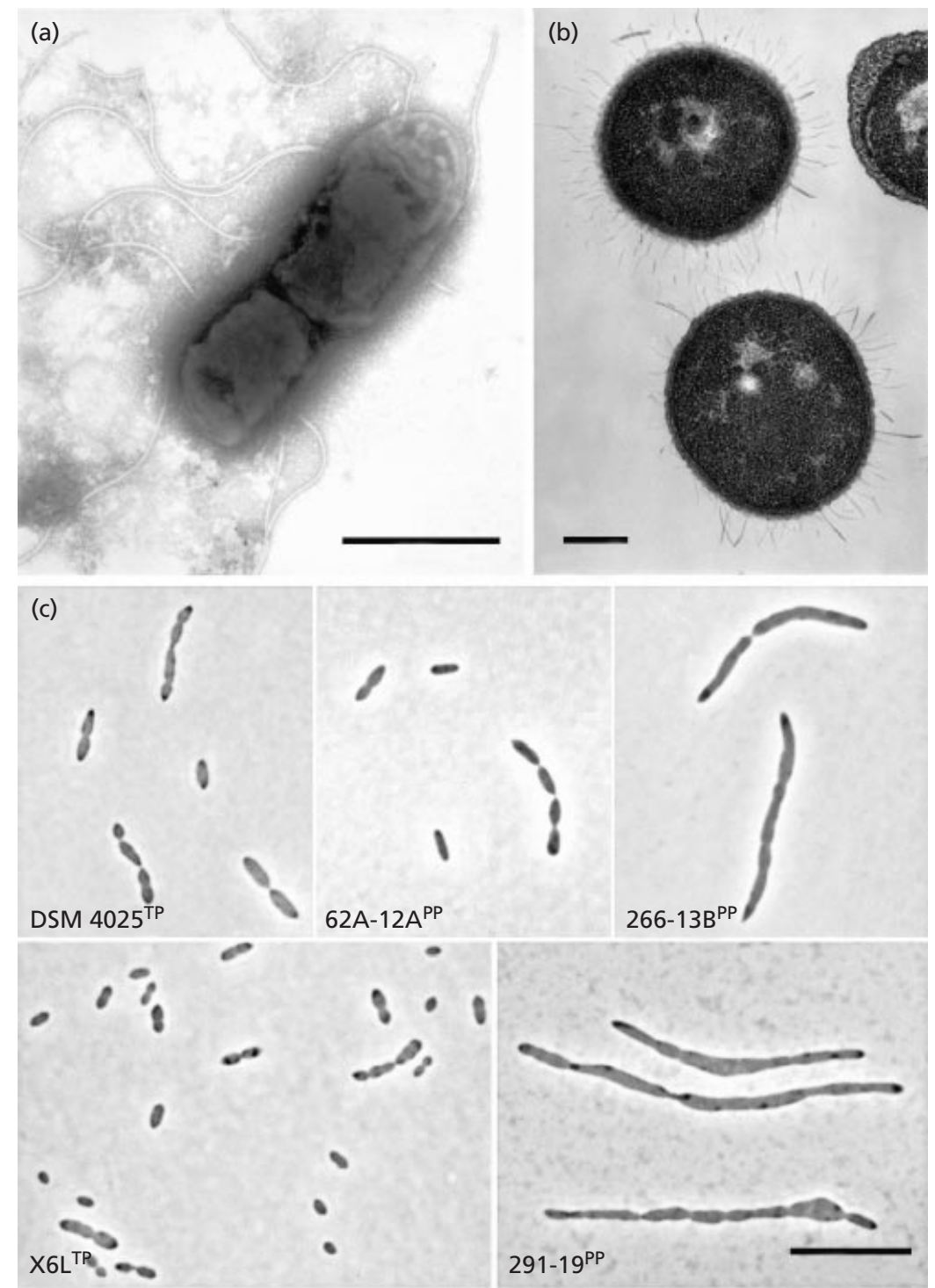

$62 A-12 A^{P P}$
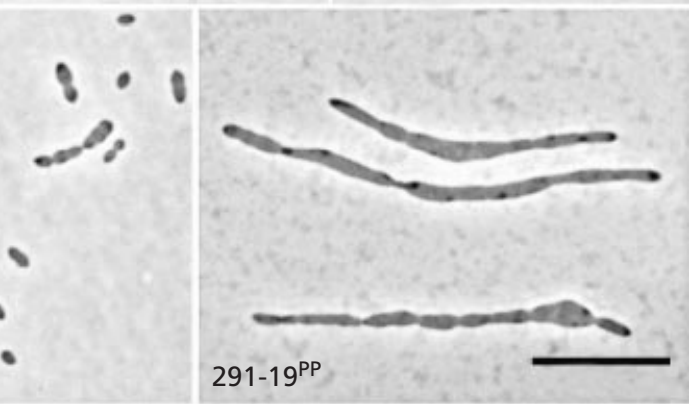

Fig. 1. (a) TEM of a negative stain of strain $X 6 L^{T P}$ demonstrating flagella, (b) TEM of thin section of strain $\mathrm{X} 6 \mathrm{~L}^{\mathrm{TP}}$ demonstrating fimbrae, (c) differences in cell morphology between strains when grown on TSB (overnight cultures). Bars: (a) $1 \mu \mathrm{m}$, (b) $0.2 \mu \mathrm{m}$, (c) $10 \mu \mathrm{m}$.

\section{Physiological and biochemical characteristics}

Phenotypic traits of Ketogulonigenium strains and selected relatives are summarized in Table 1. All five strains grew anaerobically in TSB supplemented with $1 \mathrm{~g} \mathrm{l}^{-1}$ glucose. Growth was slower anaerobically than aerobically (5-6 d for visible turbidity) and resulted in much lower cell yields. All strains were cytochromeoxidase- and catalase-positive. Only the proposed $K$. robustum isolate $\left(\mathrm{X} 6 \mathrm{~L}^{\mathrm{TP}}\right)$ was consistently positive in motility experiments. $62 \mathrm{~A}-12 \mathrm{~A}^{\mathrm{PP}}$ demonstrated motility in only one experiment (18 replicates total). The other isolates were non-motile. Only X6L ${ }^{\mathrm{TP}}$ grew at $37^{\circ} \mathrm{C}$, although growth was poor and cells had a slightly elongated and swollen appearance at that temperature. Ketogulonigenium strains grew throughout the $\mathrm{pH}$ range tested $(6 \cdot 0-8 \cdot 5)$. The optimum $\mathrm{pH}$ for $291-19^{\mathrm{PP}}$ and the proposed $K$. vulgare isolates (DSM $4025^{\mathrm{TP}}, 266-13 \mathrm{~B}^{\mathrm{PP}}$ and $62 \mathrm{~A}-12 \mathrm{~A}^{\mathrm{PP}}$ ) ranged from $7 \cdot 2$ to 8.0 and is similar to the reported optima for Roseobacter species (7.0-8.0). In contrast, X6L ${ }^{\mathrm{TP}}$ grew faster and had better cell yields at higher $\mathrm{pHs}(8 \cdot 0-8 \cdot 5)$.
This is in marked contrast to Gluconobacter, whose reported optimum $\mathrm{pH}$ ranges from $5 \cdot 5$ to $6 \cdot 0$. Although Ketogulonigenium strains grew at $\mathrm{pH} 6 \cdot 0$, growth was poor at that low $\mathrm{pH}$. In contrast to Gluconobacter, none of the Ketogulonigenium strains grew at $\mathrm{pH} 4 \cdot 5$.

$\mathrm{X} 6 \mathrm{~L}^{\mathrm{TP}}$ also differed from the other Ketogulonigenium strains in its response to $\mathrm{NaCl}$ concentration (Table 1). While all strains grew throughout the range of $0-4 \%$ added $\mathrm{NaCl}$ tested $\left(31 \cdot 2-716 \cdot 0 \mathrm{mM} \mathrm{Na} \mathrm{Na}^{+}\right.$, DSM $4025^{\mathrm{TP}}, 62 \mathrm{~A}-12 \mathrm{~A}^{\mathrm{PP}}, 266-13 \mathrm{~B}^{\mathrm{PP}}$ and $291-19^{\mathrm{PP}}$ had fastest growth rates at $0 \%$ added $\mathrm{NaCl}\left(31 \mathrm{mM} \mathrm{Na}{ }^{+}\right)$ and greatest cell yields from 0 to $2 \%$ added $\mathrm{NaCl}$ $\left(31-373 \mathrm{mM} \mathrm{Na}{ }^{+}\right)$. The growth rates of these strains consistently declined with increasing salt concentration. In contrast, the maximum growth rate of strain $\mathrm{X} 6 \mathrm{~L}^{\mathrm{TP}}$ was roughly consistent over the entire range of salt concentrations tested. However, the shortest lag periods and maximum cell yields for $\mathrm{X} 6 \mathrm{~L}^{\mathrm{TP}}$ were observed between 0.5 and $2.5 \%$ added $\mathrm{NaCl}$ (117-459 $\mathrm{mM} \mathrm{Na}{ }^{+}$. 
Table 2. Relative whole-cell fatty acid composition (\%) of strains of Ketogulonigenium and G. oxydans

Analysis was performed using a commercial system (MIS, MicroID).

\begin{tabular}{|c|c|c|c|c|c|c|}
\hline \multirow[t]{2}{*}{ Fatty acid } & \multicolumn{6}{|c|}{ Strain } \\
\hline & $\mathrm{DSM} 4025^{\mathrm{TP}}$ & $62 A-12 A^{P P}$ & $266-13 B^{P P}$ & $291-19^{P P}$ & $\mathbf{X} 6 \mathrm{~L}^{\mathrm{TP}}$ & G. oxydans \\
\hline $10: 0$ & $0 \cdot 0$ & $0 \cdot 7$ & $0 \cdot 3$ & $0 \cdot 0$ & $0 \cdot 0$ & $0 \cdot 0$ \\
\hline $10: 03-\mathrm{OH}$ & $3 \cdot 6$ & $3 \cdot 7$ & $3 \cdot 6$ & $3 \cdot 1$ & $4 \cdot 3$ & $0 \cdot 0$ \\
\hline $12: 0$ & $0 \cdot 0$ & $0 \cdot 6$ & $0 \cdot 7$ & $0 \cdot 9$ & $0 \cdot 0$ & $0 \cdot 0$ \\
\hline $12: 03-\mathrm{OH}$ & $2 \cdot 9$ & $2 \cdot 9$ & $3 \cdot 0$ & $2 \cdot 9$ & $3 \cdot 3$ & $0 \cdot 0$ \\
\hline $14: 0$ & $2 \cdot 4$ & $2 \cdot 1$ & $2 \cdot 5$ & $2 \cdot 3$ & $2 \cdot 8$ & $0 \cdot 9$ \\
\hline $14: 03-\mathrm{OH} / 16: 1$ iso $\mathrm{I}^{*}$ & $0 \cdot 0$ & $0 \cdot 0$ & $0 \cdot 0$ & $0 \cdot 0$ & $0 \cdot 0$ & $2 \cdot 0$ \\
\hline $15: 0$ & $0 \cdot 0$ & $0 \cdot 0$ & $0 \cdot 7$ & $0 \cdot 0$ & $0 \cdot 0$ & $0 \cdot 0$ \\
\hline $16: 0$ & $33 \cdot 5$ & $34 \cdot 9$ & $39 \cdot 9$ & $39 \cdot 6$ & $31 \cdot 9$ & $13 \cdot 0$ \\
\hline $16: 02-\mathrm{OH}$ & $0 \cdot 0$ & $0 \cdot 0$ & $0 \cdot 0$ & $0 \cdot 0$ & $0 \cdot 0$ & $7 \cdot 8$ \\
\hline $16: 03 \mathrm{OH}$ & $0 \cdot 0$ & $0 \cdot 0$ & $0 \cdot 0$ & $0 \cdot 0$ & $0 \cdot 0$ & $2 \cdot 5$ \\
\hline $16: 1 \omega 7 c / 15$ iso $2-\mathrm{OH} \dagger$ & $2 \cdot 7$ & $3 \cdot 8$ & $5 \cdot 5$ & $5 \cdot 3$ & $2 \cdot 8$ & $0 \cdot 0$ \\
\hline $18: 0$ & $2 \cdot 9$ & $1 \cdot 1$ & $0 \cdot 7$ & $0 \cdot 9$ & $0 \cdot 0$ & $1 \cdot 6$ \\
\hline $18: 12-\mathrm{OH}$ & $0 \cdot 0$ & $0 \cdot 0$ & $0 \cdot 0$ & $0 \cdot 0$ & $0 \cdot 0$ & $1 \cdot 7$ \\
\hline $18: 1 \omega 7 c / \omega 9 t / \omega 12 t+$ & $52 \cdot 0$ & $49 \cdot 5$ & $41 \cdot 4$ & $43 \cdot 5$ & $54 \cdot 9$ & $65 \cdot 8$ \\
\hline un $18.846 / 18.858 \S$ & $0 \cdot 0$ & $0 \cdot 7$ & $1 \cdot 7$ & $1 \cdot 4$ & $0 \cdot 0$ & $0 \cdot 0$ \\
\hline 19:0 cyclo $8 c$ & $0 \cdot 0$ & $0 \cdot 0$ & $0 \cdot 0$ & $0 \cdot 0$ & $0 \cdot 0$ & $2 \cdot 9$ \\
\hline $20: 3 \omega 6,9,12 c$ & $0 \cdot 0$ & $0 \cdot 0$ & $0 \cdot 0$ & $0 \cdot 0$ & $0 \cdot 0$ & $1 \cdot 7$ \\
\hline
\end{tabular}

* Summed feature 3 .

$\uparrow$ Summed feature 4.

+ Summed feature 7 .

§Summed feature 9; un, undetermined fatty acid.

There were only slight differences in carbon utilization between the five strains. All five Ketogulonigenium strains utilized arabinose, cellobiose, glucose, glycerol, inositol, lactose, maltose, mannitol, mannose, rhamnose, sorbitol and sorbose. Differences in carbon utilization between the strains are listed in Table 1 . Carbon sources resulting in fastest growth and highest cell yields were the sugar alcohols mannitol, inositol, gycerol and sorbitol, along with lactose and arabinose. Although L-sorbose was used for the original enrichments and was utilized by all strains, cultures attained a lower turbidity on L-sorbose when compared to most of the other carbon sources tested. Carbon utilization and oxidation was tested by conventional methods and by BIOLOG, respectively. The BIOLOG carbohydrate data were in general agreement with that from conventional methods.

The whole-cell fatty acid (FAME) compositions of the strains are shown in Table 2 . The two main fatty acids were saturated hexadecanoic acid (16:0) (31.9-39.9\% of total cellular fatty acids) and summed feature 7 $(18: 1 \omega 7 c / \omega 9 t / \omega 12 t)(41.4-54.9 \%$ of total cellular fatty acids). When compared to the MIDI databases, fatty acid profile matching indexes for the Ketogulonigenium strains ranged from $0 \cdot 144-0 \cdot 228$, well below the recommended threshold for reliable identification by MIDI $(0 \cdot 500)$.
MICs $\left(\mu \mathrm{g} \mathrm{ml}^{-1}\right)$ of the following antibiotics were identical for all five strains: amikacin (2.0), amoxicillin/clavulonic acid $(1 / 0 \cdot 5)$, ampicillin $(0 \cdot 5)$, cefazolin $(1 \cdot 0)$, cefoxitin $(1 \cdot 0)$, ceftazidime $(2 \cdot 0)$, ceftiofur $(0 \cdot 06)$, cephalothin $(1 \cdot 0)$, enrofloxacin $(0 \cdot 03)$, imipenem $(1 \cdot 0)$, kanamycin $(4 \cdot 0)$, tetracycline $(0 \cdot 25)$, ticarcillin $(8 \cdot 0)$, trimethoprim/sulfamethoxazole (4/76). Antibiotic MIC differences between strains are listed in Table 1. All of the Ketogulonigenium strains tested were inhibited by relatively low concentrations of the antibacterial agents tested and would normally be considered 'sensitive' to the antibiotics, with the exception of the trimethoprim/sulfamethoxazole combination. Clinical isolates inhibited by those concentrations of trimethoprim/sulfamethoxazole would normally be considered to be 'resistant'. However, because most of the Ketogulonigenium strains do not grow at $37^{\circ} \mathrm{C}$, these tests could not be performed in accordance with NCCLS standardized procedures and NCCLS interpretive criteria cannot be applied reliably.

\section{Genotypic analyses}

Four of the Ketogulonigenium strains had almost identical chromosomal $\mathrm{G}+\mathrm{C}$ content (53.4$54.0 \mathrm{~mol} \%$; Table 1). Only X6L ${ }^{\mathrm{TP}}$ differed slightly from the others $(52 \cdot 1 \pm 0 \cdot 3 \%)$. The Ketogulonigenium $\mathrm{G}+\mathrm{C}$ values are lower than the reported values 


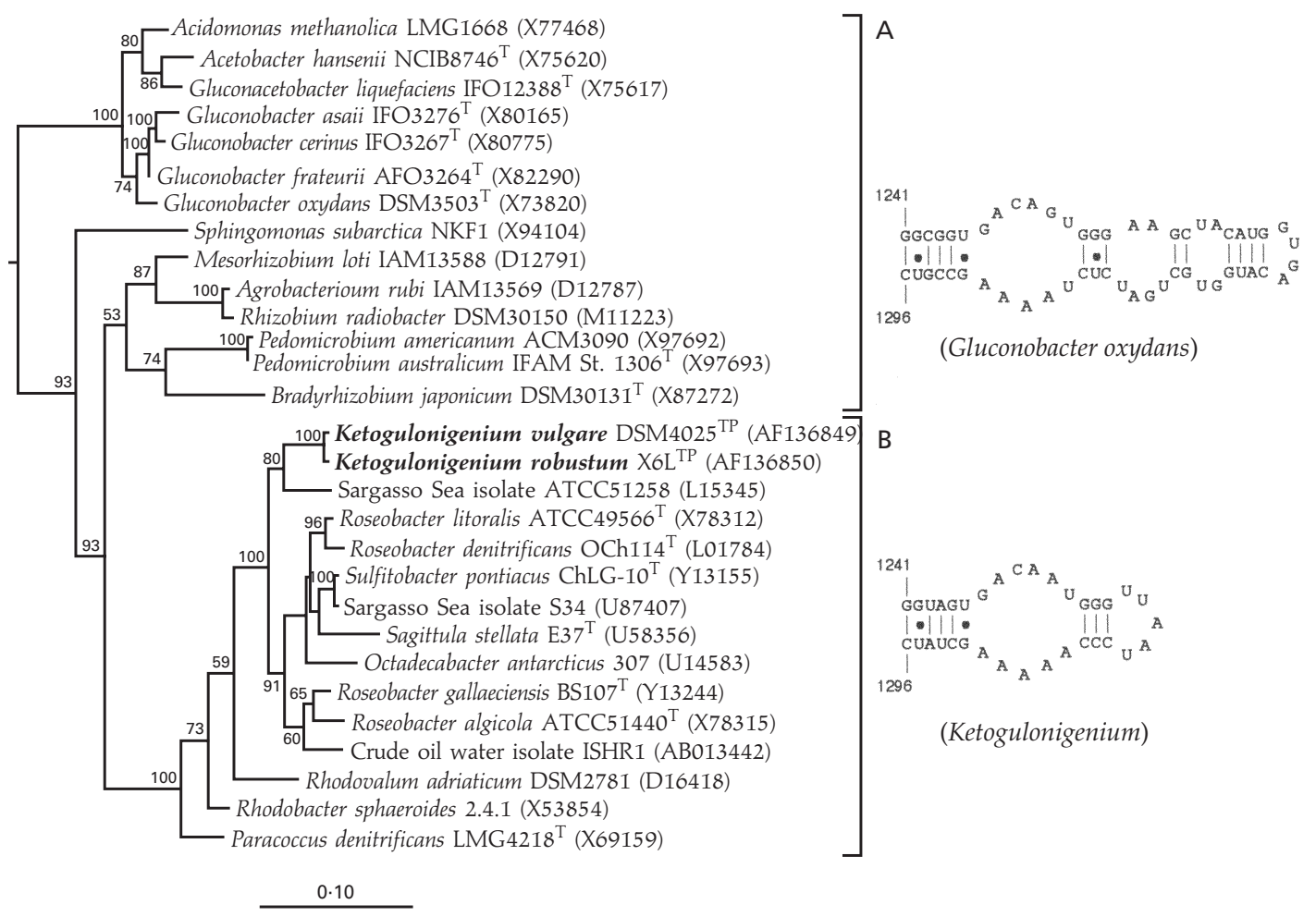

Fig. 2. Phylogenetic relationships and supporting structural elements of Ketogulonigenium species and selected relatives. The tree was produced by a maximum-likelihood method using fastDNAml_loop (Olsen et al., 1994) and was rooted using E. coli 16S rRNA. Bootstrap values were calculated using fastDNAml_boot (Olsen et al., 1994). The nodes without bootstrap values represent either branching orders that were inconsistent between the phylogenetic tree and the consensus tree generated from 100 bootstrap trees or had bootstrap values of $50 \%$ or less. The scale bar represents 0.1 changes per nucleotide position. The numbering of nucleotide positions in the rRNA stem-loop structures are based upon E. coli numbering and illustrate the abbreviated stem-loop structure found in Ketogulonigenium. This truncated stem-loop structure is shared by all members of the assemblage designated ' $B$ ' and serves to distinguish them from the genera Gluconobacter and Acetobacter and some other members of the $\alpha$-Proteobacteria (designated assemblage 'A').

for $R$. litoralis $(56 \cdot 3-58 \cdot 1 \mathrm{~mol} \%), R$. denitrificans $(59.6 \mathrm{~mol} \%)$ and G. oxydans $(56-64 \mathrm{~mol} \%)$. Our calculated value of $60.7 \mathrm{~mol} \% \mathrm{G}+\mathrm{C}$ for Spirochaeta aurantia strain $\mathrm{J} 1^{\mathrm{T}}$ was consistent with the published value of $60.0 \mathrm{~mol} \%$ (Breznak \& Canale-Parola, 1975) and served as a measure of accuracy for our experimental results. The $\mathrm{CsCl}$ gradients and agarose gel electrophoresis revealed that strains $\mathrm{X} 6 \mathrm{~L}^{\mathrm{TP}}$ and 291-19 ${ }^{\mathrm{PP}}$ contained plasmids (Table 1).

The similarities in small subunit rDNA sequence among the five Ketogulonigenium strains ranged from $99 \cdot 7$ to $100 \%$. Strains $266-13 \mathrm{~B}^{\mathrm{PP}}, 291-19^{\mathrm{PP}}$ and $62 \mathrm{~A}-$ $12 \mathrm{~A}^{\mathrm{PP}}$ had identical 16S rDNA sequences over 1354 comparable nucleotide positions. DSM $4025^{\mathrm{TP}}$ differed from these three strains at a single nucleotide position. Strain X6L $\mathrm{L}^{\mathrm{TP}}$ differed from DSM $4025^{\mathrm{TP}}$ at five nucleotide positions and from the other three strains at four positions. All of the phylogenetic analyses tested placed the five strains within the 'Rhodobacter group' of the Ribosome Database Project II (Maidak et al., 2000) in the $\alpha$-subclass of the Proteobacteria (Fig. 2, assemblage 'B'). The most similar sequence in the public databases was that of strain LFR (93.7-94.2\% identical), a dimethyl- sulfonioproprionate (DSMP)-degrader isolated from the Sargasso Sea (Ledyard et al., 1993). The described genus most closely related to Ketogulonigenium was Roseobacter (Fig. 2; 92.1-92.8\% identical), a genus composed of photosynthetic, marine organisms (Lafay et al., 1995; Ruiz-Ponte et al., 1998; Shiba, 1991). More distantly related were the genera Gluconobacter and Acetobacter (Fig. 2; 81.8-83.3\% identical and $81 \cdot 2-82 \cdot 1 \%$ identical, respectively). The phylogeny is supported by an abbreviated stem-loop structure (helixes 45 and 46; as numbered by Van de Peer et al., 1996) found in Ketogulonigenium (Fig. 2, assemblage B) that is shared by all members of the 'Rhodobacter group' and serves to distinguish this group from most of the other $\alpha$-Proteobacteria (Fig. 2, assemblage A). The recently described acetic acid $\alpha$-proteobacterium Asaia bogorensis (Yamada et al., 2000) was also more distantly related (82.8-83.1\% identical) and lacked the truncated stem-loop structure found in Ketogulonigenium. Branch lengths and branching order of the phylogenetic tree suggest the five strains represent a genus of $\alpha$-Proteobacteria not currently represented in the rRNA databases.

Results of DNA reassociation experiments are listed in 
Table 3. DNA-DNA reassociation values (\%) among Ketogulonigenium isolates and Roseobacter type strains

Mean values for reciprocal DNA-DNA hydridizations ( $n=1-5$ replicates) among the proposed species are boxed: $K$. vulgare is represented by strains DSM $4025^{\mathrm{TP}}, 62 \mathrm{~A}-12 \mathrm{~A}^{\mathrm{PP}}$ and $266-13 \mathrm{~B}^{\mathrm{PP}}$; K. robustum is represented by strain $\mathrm{X} 6 \mathrm{~L}^{\mathrm{TP}}$. Strain $291-19^{\mathrm{PP}}$ was not assigned to either species in this study (see text). Reassociation between homologous DNAs was defined as $100 \%$.

\begin{tabular}{|c|c|c|c|c|c|c|c|}
\hline \multirow[t]{2}{*}{ Source of target DNA } & \multicolumn{7}{|c|}{ Source of target DNA } \\
\hline & DSM $4025^{\mathrm{TP}}$ & $62 A-12 A^{P P}$ & $266-13 B^{P P}$ & $291-19^{\mathrm{PP}}$ & $\mathbf{X 6 L ^ { T P }}$ & R. litoralis $\dagger$ & R. denitrificans \\
\hline $\mathrm{DSM} 4025^{\mathrm{TP}}$ & 100 & $92 \pm 3$ & $93 *$ & $49 \pm 4$ & $14 \pm 2$ & $10 \pm 3$ & $12 \pm 3$ \\
\hline $62 \mathrm{~A}-12 \mathrm{~A}^{\mathrm{PP}}$ & $88 \pm 1$ & 100 & $91 *$ & $42 \pm 8$ & $18 \pm 3$ & $11 \pm 2$ & $14 \pm 1$ \\
\hline $266-13 \mathrm{~B}^{\mathrm{PP}}$ & $94 *$ & $70 *$ & 100 & $63 \pm 10$ & $11 \pm 2$ & $10 \pm 1$ & $13 \pm 2$ \\
\hline $291-19^{\mathrm{PP}}$ & $36 \pm 17$ & $31 \pm 9$ & $52 \pm 10$ & 100 & $9 \pm 2$ & $7 \pm 0$ & $8 \pm 1$ \\
\hline $\mathrm{X} 6 \mathrm{~L}^{\mathrm{TP}}$ & $38 \pm 9$ & $37 \pm 5$ & $40 \pm 3$ & $18 \pm 4$ & 100 & $4 \pm 2$ & $4 \pm 2$ \\
\hline R. litoralis $\dagger$ & $15^{*}$ & ND & $17 *$ & ND & ND & 100 & $33^{*}$ \\
\hline R. denitrificanst & $18 *$ & ND & $12 *$ & ND & ND & ND & 100 \\
\hline
\end{tabular}

* Based upon a single hybridization experiment.

$\dagger$ ATCC $49566^{\mathrm{T}}$.

† ATCC $33942^{\mathrm{T}}$.

Table 3. Based upon the phylogenetic definition of a species as strains with approximately $70 \%$ DNADNA relatedness (Wayne et al., 1987), we have divided the five strains into two species. The first consists of $266-13 \mathrm{~B}^{\mathrm{PP}}, 62 \mathrm{~A}-12 \mathrm{~A}^{\mathrm{PP}}$ and DSM $4025^{\mathrm{TP}}$ (with the proposed name $K$. vulgare sp. nov.) and the second consists of $\mathrm{X}_{6} \mathrm{~L}^{\mathrm{TP}}$ (proposed name $K$. robustum sp. nov.). The species affiliation of strain $291-19^{\mathrm{PP}}$ was left undetermined (see discussion below).

\section{DISCUSSION}

Although bacteria from several genera oxidize Lsorbose to 2-keto-L-gulonic acid (Imai et al., 1990; Sugisawa et al., 1990; Yin et al., 1990; Nogami et al., 1995), the yield is generally insufficient to warrant commercial production of 2-KLG, a key intermediate in the chemical synthesis of vitamin C. We initiated a search for bacteria that generated higher yields of 2KLG through the use of enrichment cultures supplemented with L-sorbose. A high concentration of Lsorbose was used in initial enrichments to provide sufficient substrate to achieve detectable levels of 2KLG despite the potential for 2-KLG-degrading organisms to be active in the mixed-culture enrichments. This high sugar concentration also simulated the conditions envisioned for commercial production of 2-KLG and provided a degree of osmotic selection for organisms capable of growing under production conditions. Similarly, corn steep liquor was used in enrichments and isolation media to simulate the expected commercial production medium. Calcium carbonate was included to limit the potential acidification of the medium resulting from the oxidation of substrates to acidic end products. Considering the subsequent discovery that these organisms produce large amounts of organic acids from carbohydrates, and generally grow poorly at $\mathrm{pHs}$ below 7.0, the inclusion of calcium carbonate may have been critical for obtaining successful enrichment cultures. In screening the enrichments for individual microbes that produced $2-\mathrm{KLG}$, plates were examined under $\times 8$ to $\times 40$ magnification after 24 and $48 \mathrm{~h}$ of incubation. Attention to the smallest and slowest-growing colonies proved necessary to recover 2-KLG-producing strains from the dilution plates. Three previously described 2KLG-producing strains yielded higher product concentrations when grown in co-culture with a second, 'helper' species (Imai et al., 1990; Yin et al., 1990; Nogami et al., 1995). It was reasoned that enrichments positive for 2-KLG production could have resulted from the presence of at least one helper strain. To allow for this possibility, strains we isolated were screened for 2-KLG production in all possible pairwise combinations as well as individually. All strains that produced $2-$ KLG did so both individually and in paired combinations.

Four strains isolated during this study, each from a different enrichment, converted L-sorbose to 2-KLG efficiently: strains $266-13 \mathrm{~B}^{\mathrm{PP}}, 291-19^{\mathrm{PP}}, 62 \mathrm{~A}-12 \mathrm{~A}^{\mathrm{PP}}$ and $\mathrm{X} 6 \mathrm{~L}^{\mathrm{TP}}$. Although the four isolates were obtained from geographically distinct locations, their $16 \mathrm{~S}$ rDNA sequences were nearly identical to each other (99.7-100\% identical). Comparative 16S rDNA sequencing subsequently revealed that they were also nearly identical (99.6-99.9\% identical) to the $16 \mathrm{~S}$ rDNA sequence from DSM $4025^{\mathrm{TP}}$, a patent strain originally identified as Gluconobacter oxydans (Yin et al., 1990). Together, the five sequences formed a monophyletic group within the $\alpha$-Proteobacteria (Fig. 2 ). The low sequence similarity (92-94\% identical) between the 16S rDNA sequences from these five strains and any previously named bacteria suggested the need for creation of a new bacterial genus. We propose the new genus be named Ketogulonigenium 
based on the conspicuous production of 2-keto-Lgulonic acid from L-sorbose by members of the proposed taxon. The newly isolated strains and strain DSM $4025^{\mathrm{TP}}$ were distinguishable from Roseobacter, the nearest phylogenetic relative, and from Gluconobacter and Acetobacter, the other genera of $\alpha$ Proteobacteria that oxidize L-sorbose to 2-KLG (Imai et al., 1990; Sugisawa et al., 1990; Yin et al., 1990; Nogami et al., 1995).

Although the isolates characterized in this study are similar to Roseobacter strains in that they are catalasepositive and oxidase-positive, there exist major phenotypic differences related to the energy metabolism of the two groups. The genus Roseobacter is comprised aerobic, photosynthetic, mobile, pink-pigmented, marine bacteria, which contain bacteriochlorophyll $a$ (Lafay et al., 1995; Ruiz-Ponte et al., 1998; Shiba, 1991). Strains of the proposed genus Ketogulonigenium are facultatively anaerobic chemoheterotrophs, do not contain bacteriochlorophyll $a$, and produce a diffusible, brown pigment. In addition, the 2-KLG-producing strains have a lower $\mathrm{G}+\mathrm{C}$ content $(52 \cdot 1-$ $54.0 \mathrm{~mol} \%$ ) and a higher and narrower optimum temperature range $\left(27-31^{\circ} \mathrm{C}\right)$ than those of Roseobacter species $\left(56-60 \mathrm{~mol} \%\right.$ and $20-30{ }^{\circ} \mathrm{C}$, respectively; Shiba, 1992).

The strains characterized in this study were not closely related to Gluconobacter or Acetobacter (81-83\% 16S rDNA identity), but they did share a number of important phenotypic traits characteristic of these $\alpha$ proteobacteria. Like Gluconobacter and Acetobacter, the five proposed Ketogulonigenium isolates oxidize Lsorbose to 2-KLG (although with greater efficiencies) and glucose to 2-keto-gluconic acid. Nonetheless, there were numerous phenotypic traits that distinguish the new isolates from Gluconobacter and Acetobacter. Members of both Gluconobacter and Acetobacter grow at $\mathrm{pH} 4.5$ and have $\mathrm{pH}$ optima between 5.4 and 6.3 (De Ley \& Swings, 1984; De Ley et al., 1984). The strains described here were decidedly not acidophilic, growing optimally in the $\mathrm{pH}$ range of $7 \cdot 2-8 \cdot 5$. All five strains grew at $\mathrm{pH} 6 \cdot 0$, though growth rates were slow and cell yields were low: no growth was observed at $\mathrm{pH} 4 \cdot 5$. In addition, cultures of Gluconobacter and Acetobacter accumulate dihydroxyacetone when glycerol is supplied as a carbon source (data not shown), whereas the five strains described here do not. Gluconobacter and Acetobacter also contain elements of primary $16 \mathrm{~S}$ rDNA sequence (Fig. 2) that distinguish them and the other $\alpha$-Proteobacteria from the five Ketogulonigenium strains and other members of the Rhodobacter group. Phylogenetic and phenotypic data strongly support the hypothesis that the newly isolated strains are not members of the genus Gluconobacter or Acetobacter. Furthermore, the data also contradict the original identification of strain DSM $4025^{\mathrm{TP}}$ as $G$. oxydans (Yin et al., 1990) and support reclassification of the strain within the proposed genus Ketogulonigenium.

Although rRNA-based phylogeny suggested the creation of a new genus to accommodate these five strains,
16S rRNA sequences generally lack the variability required to make species-level distinctions. Therefore, DNA-DNA reassociation studies were undertaken to address species-level relationships. Based on DNADNA hybridization results, we propose dividing the five strains into two species. The first species would consist of strains $266-13 \mathrm{~B}^{\mathrm{PP}}, 62 \mathrm{~A}-12 \mathrm{~A}^{\mathrm{PP}}$ and DSM $4025^{\mathrm{TP}}$ (with the proposed name $K$. vulgare sp. nov.) and the second would consist of strain X6L ${ }^{\mathrm{TP}}$ (proposed name $K$. robustum sp. nov.). The low DNADNA reassociation values between $291-19^{\mathrm{PP}}$ and the other strains (Table 3) suggest that this strain should also be given species distinction. However, the phenotypic data did not support distinction from $K$. vulgare (Tables 1 and 2). Also, DNA-DNA reassociation values greater than $70 \%$ were occasionally recorded with members of the $K$. vulgare group. Because of these findings, we have chosen to leave the species status of 291-19 ${ }^{\mathrm{PP}}$ unresolved at this time.

The proposed creation of the species $K$. robustum (strain $\mathrm{X} 6 \mathrm{~L}^{\mathrm{TP}}$ ) and $K$. vulgare $\left(266-13 \mathrm{~B}^{\mathrm{PP}}, 62 \mathrm{~A}-12 \mathrm{~A}^{\mathrm{PP}}\right.$ and DSM $4025^{\mathrm{TP}}$ ) is supported by phenotypic characterization of the strains (Table 1). Strain $\mathrm{X} 6 \mathrm{~L}^{\mathrm{TP}}$ was more robust than the other strains, routinely growing faster and with greater cell yields over a broader range of conditions. Strain $\mathrm{X} 6 \mathrm{~L}^{\mathrm{TP}}$ was also the only motile strain and the only one capable of growing at $37^{\circ} \mathrm{C}$. While cells of strains $291-19^{\mathrm{PP}}, 266-13 \mathrm{~B}^{\mathrm{PP}}, 62 \mathrm{~A}-12 \mathrm{~A}^{\mathrm{PP}}$ and DSM $4025^{\mathrm{TP}}$ were frequently elongated when grown on some media (Fig. 1c), cells of strain X6L $\mathrm{L}^{\mathrm{TP}}$ were consistently ovoid to rod-shaped and were unique amongst the strains in resisting decolorization during the Gram stain. The $\mathrm{pH}$ optimum of $\mathrm{X} 6 \mathrm{~L}^{\mathrm{TP}}$ was higher $(8 \cdot 0-8 \cdot 5)$ than those of the other strains $(7 \cdot 2-8 \cdot 0)$ and its response to $\mathrm{Na}^{+}$concentration also differed dramatically (Table 1). The $\mathrm{G}+\mathrm{C}$ content of $\mathrm{X} 6 \mathrm{~L}^{\mathrm{TP}}$ was also lower $(52 \cdot 1 \mathrm{~mol} \%)$ than that of the other strains $(53 \cdot 4-54 \cdot 0 \mathrm{~mol} \%)$.

Although patterns of carbon utilization and antibiotic sensitivity are frequently used to discriminate amongst species within a genus, differences in carbon utilization and antibiotic sensitivity patterns were subtle amongst the Ketogulonigenium isolates. The lack of differences in antibiotic sensitivity patterns amongst the five strains suggests that none of the plasmids present in strains $\mathrm{X}_{6 \mathrm{~L}}^{\mathrm{TP}}$ and $291-19^{\mathrm{PP}}$ expressed antibiotic resistance.

In summary, four environmental isolates and one culture collection strain that converted L-sorbose to 2KLG were characterized phenotypically and genotypically. Our analyses suggest these strains represent a new genus within the $\alpha$-Proteobacteria, for which we propose the name Ketogulonigenium. Two species were identified within the new genus with the proposed names $K$. vulgare and $K$. robustum.

\section{Description of Ketogulonigenium gen. nov.}

Ketogulonigenium (Ke.to.gu.lo.ni.ge'ni.um. N.L. n. acidum ketogulonicum ketogulonic acid; N.L. neut. 
suff. genium that which produces, N.L. neut. n. Ketogulonigenium that which produces ketogulonic acid).

Gram-negative, facultatively anaerobic, motile or nonmotile, ovoid to rod-shaped cells, $0 \cdot 8-1 \cdot 3 \mu \mathrm{m}$ long, $0.5-0.7 \mu \mathrm{m}$ in diameter, with tapered ends, occurring as single cells, pairs and occasionally short chains. Some strains form elongated cells (up to $30 \mu \mathrm{m}$ in length) on TSB. Flagella and fimbrae have been observed. Colonies are tan-coloured, smooth, circular, entire, raised to convex, $1-2 \mathrm{~mm}$ in diameter with a diffusible brown pigment after $48 \mathrm{~h}$ incubation. Oxidase and catalase reactions are positive. Optimum temperature range is $27-31{ }^{\circ} \mathrm{C}$, optimum $\mathrm{pH}$ range is $7 \cdot 2-8 \cdot 5$ and optimum $\mathrm{Na}^{+}$concentration is $117-$ $459 \mathrm{mM}$. Chemoorganotrophic. Carbon sources utilized include arabinose, cellobiose, fructose, glucose, glycerol, inositol, lactose, maltose, mannitol, mannose, rhamnose, sorbitol, sorbose, sucrose, trehalose, pyruvate and succinate. Favoured carbon sources are inositol, mannitol, glycerol, sorbitol, lactose and arabinose. All strains examined produce 2-keto-L-gulonic acid from L-sorbose. Major cellular fatty acids are 16:0 and 18:1 $\omega 7 c / \omega 9 t / \omega 12 t$ and the DNA G + C content is $52 \cdot 1-54 \cdot 0 \%$. Small subunit rDNA sequence analysis places this genus in the $\alpha$-subclass of the Proteobacteria. All strains isolated in the present study originated in soil. The DNA reassociation studies divide the genus into two species, $K$. vulgare and $K$. robustum, of which $K$. vulgare is the designated type species.

\section{Description of Ketogulonigenium vulgare sp. nov.}

Ketogulonigenium vulgare (vul.ga're. L. neut. adj. vulgare common).

Members of this species are non-motile and fail to grow at $37^{\circ} \mathrm{C}$. The optimum $\mathrm{pH}$ range is $7 \cdot 2-8 \cdot 0$ and the $\mathrm{G}+\mathrm{C}$ content of identified strains is 53.4 $54.0 \mathrm{~mol} \%$. Strain $62 \mathrm{~A}-12 \mathrm{~A}^{\mathrm{PP}}$ produces a flocculent turbidity in broth cultures. Other properties of this species are as described for the genus. Based upon DNA reassociation studies, three strains are included in this species; $266-13 \mathrm{~B}^{\mathrm{PP}}, 62 \mathrm{~A}-12 \mathrm{~A}^{\mathrm{PP}}$ and DSM $4025^{\mathrm{TP}}$, of which DSM $4025^{\mathrm{TP}}$ is the designated type strain.

\section{Description of the type strain}

The optimum $\mathrm{pH}$ range of DSM $4025^{\mathrm{TP}}$ is $7 \cdot 5-8.0$ and its $\mathrm{G}+\mathrm{C}$ content is $54.0 \mathrm{~mol} \%$. Pigment production in this strain is more pronounced than in other members of the species. Other properties of the type strain are as described for the species.

\section{Description of Ketogulonigenium robustum sp. nov.}

Ketogulonigenium robustum (ro.bust'um. L. adj. robustum strong).

Cells are motile, resist decolorization when Gramstained, and are $0.8-1.0 \mu \mathrm{m}$ in length and $0.6-0.7 \mu \mathrm{m}$ wide regardless of the medium used in this study.
Colonies are visible on solid media after $24 \mathrm{~h}$ and pigment production is poor and sporadic. Growth is observed at $37^{\circ} \mathrm{C}$. The $\mathrm{G}+\mathrm{C}$ content of the DNA is slightly lower $(52 \cdot 1 \pm 0 \cdot 3 \mathrm{~mol} \%)$ and the $\mathrm{pH}$ optimum is slightly higher $(8 \cdot 0-8 \cdot 5)$ than those of the other members of the genus $(53 \cdot 4-54.0 \mathrm{~mol} \%$ and $7 \cdot 2-8 \cdot 0$ respectively). The one identified strain of this species grows faster and with greater cell yields than other members of the genus so far described. Other properties are as described for the genus. The type and only identified strain is $\mathrm{X} 6 \mathrm{~L}^{\mathrm{TP}}(=\mathrm{NRRL}$ B-21627 = KCTC 0858BP).

\section{ACKNOWLEDGEMENTS}

The authors would like to thank Dr Robert Walker and staff at the Michigan State University Animal Health Diagnostic Laboratory for performing antibiotic MIC tests, Tracy Pepper and Dr Harry Horner of the Bessie Microscopy Center at Iowa State University and Sally Burns at the Center for Electron Optics at Michigan State University for help with electron microscopy and image analysis, Rebecca Wolter and Danielle Rhine for technical assistance with screening isolates, Dr John Breznak for supplying Spirochaeta aurantia strain $\mathrm{J} 1^{\mathrm{T}}$, Dr Frank Löffler for help with preparation of anaerobic media and Ms Shirley Landon for help with phenotypic testing.

\section{REFERENCES}

Altshul, S. F., Gish, W., Miller, W., Myers, E. W. \& Lipman, D. J. (1990). Basic local alignment search tool. J Mol Biol 215, 403-410.

Breznak, J. \& Canale-Parola, E. (1975). Morphology and physiology of Spirochaeta aurantia strains isolated from aquatic habitats. Arch Microbiol 105, 1-12.

De Ley, J. \& Swings, J. (1984). Genus II. Gluconobacter. In Bergey's Manual of Systematic Bacteriology, vol. 1, pp. 275-278. Edited by N. R. Kreig \& J. G. Holt. Baltimore: Williams \& Wilkins.

De Ley, J., Swings, J. \& Gosselé, F. (1984). Genus I. Acetobacter. In Bergey's Manual of Systematic Bacteriology, vol. 1, pp. 268-274. Edited by N. R. Kreig \& J. G. Holt. Baltimore: Williams \& Wilkins.

Delić, V., Šunić, D. \& Vlašić, D. (1989). Microbial reactions for the synthesis of vitamin C (L-ascorbic acid). In Biotechnology of Vitamins, Pigments and Growth Factors, pp. 299-336. Edited by E. J. Vandamme. London: Elsevier Applied Science.

DeSoete, G. (1983). On construction of 'optimal' phylogenetic trees. $Z$ Naturforsch Sect $C J$ Biosci 38, 156-158.

Eden, P. A., Schmidt, T. M., Blakemore, R. P. \& Pace, N. R. (1991). Phylogenetic analysis of Aquaspirillum magnetotacticum using PCR-amplified 16S rRNA-specific DNA. Int J Syst Bacteriol 41, 324-325.

Imai, K., Sakane, T. \& Nogami, I. (1990). Biologically pure cultures of Pseudomonas sorbooxidans useful for producing 2keto-L-gulonic acid. US Patent 4, 933,289.

Koneman, E., Allen, S., Dowell, V. \& Sommers, H. (1979). Color Atlas and Textbook of Diagnostic Microbiology, pp. 216-217. Philadelphia: Lippencott. 
Lafay, B., Ruimy, R., Rausch de Traubenberg, C., Breittmayer, V., Gauthier, M. J. \& Christen, R. (1995). Roseobacter algicola sp. nov., a new marine bacterium isolated from the phycosphere of the toxin-producing dinoflagellate Prorocentrum lima. Int J Syst Bacteriol 45, 290-296.

Ledyard, K. M., Delong, E. F. \& Dacey, J. W. H. (1993). Characterization of a DSMP-degrading bacterial isolate from the Sargasso Sea. Arch Microbiol 160, 312-318.

Maidak, B. L., Cole, J. R., Lilburn, T. G. \& 8 other authors (2000). The RDP (Ribosomal Database Project) continues. Nucleic Acids Res 28, 173-174.

Marmer, J. \& Doty, P. (1962). Determination of the base composition of deoxyribonucleic acid from its thermal denaturation temperature. J Mol Biol 5, 109-118.

Nogami, I., Shirafuji, H., Oka, M. \& Yamaguchi, T. (1995). Method for producing 2-keto-L-gulonic acid. US Patent 5,474,924.

Olsen, G. J., Matsuda, H., Hagstrom, R. \& Overbeek, R. (1994). FastDNAml: a tool for the construction of phylogenetic trees of DNA sequences using maximum likelihood. Comput Appl Biosci 10, 41-48

Reichstein, T. \& Grussner, A. (1934). Eine ergiebige synthese der 1-ascorbinsaure. Helv Chim Acta 17, 311-328.

Ruiz-Ponte, C., Cilia, V., Lambert, C. \& Nicolas, J. L. (1998). Roseobacter gallaeciensis sp. nov., a new marine bacterium isolated from rearings and collectors of the scallop Pecten maximus. Int J Syst Bacteriol 48, 537-542.

Saitou, N. \& Nei, M. (1987). The neighbor-joining method: a new method for reconstructing phylogenetic trees. Mol Biol Evol 4, 406-425.

Sambrook, J., Fritsch, E. F. \& Maniatis, T. (1989a). Molecular Cloning : a Laboratory Manual, 2nd edn, p. B.20. Cold Spring Harbor, NY: Cold Spring Harbor Laboratory.

Sambrook, J., Fritsch, E. F. \& Maniatis, T. (1989b). Molecular Cloning: a Laboratory Manual, 2nd edn, p. 1.42. Cold Spring Harbor, NY : Cold Spring Harbor Laboratory.
Sambrook, J., Fritsch, E. F. \& Maniatis, T. (1989c). Molecular Cloning: a Laboratory Manual, 2nd edn, p. B.15. Cold Spring Harbor, NY: Cold Spring Harbor Laboratory.

Shiba, T. (1991). Roseobacter litoralis gen. nov., sp. nov., and Roseobacter denitrificans sp. nov., aerobic pink-pigmented bacteria that contain bacteriochlorophyll a. Syst Appl Microbiol 14, 140-145.

Shiba, T. (1992). The genus Roseobacter. In The Prokaryotes, 2nd edn, pp. 2156-2159. Edited by A. Belows, H. G. Trüper, M. Dworkin, W. Harder \& K.-H. Scheifer. New York: Springer.

Sugisawa, T., Hoshino, T., Masuda, S., Nomura, S., Setoguchi, Y., Tazoe, M., Shinjoh, M., Someha, S. \& Fujiwara, A. (1990). Microbial production of 2-keto-L-gulonic acid from L-sorbose and D-sorbitol by Gluconobacter melanogenus. Agric Biol Chem 54, 1201-1209.

Tengerdy, P. R. (1961a). Redox potential changes in the 2-ketoL-gulonic acid fermentation. I. Correlation between redox potential and dissolved oxygen concentration. $J$ Biochem Microbiol Technol Eng 3, 241-253.

Tengerdy, P. R. (1961b). Redox potential changes in the 2-ketoL-gulonic acid fermentation. II. Correlation between redox potential and product formation. $J$ Biochem Microbiol Tech Eng 3, 255-260.

Van de Peer, Y., Nicolai, S., De Rijk, P. \& De Wachter, R. (1996). Database on the structure of small ribosomal subunit RNA. Nucleic Acids Res 24, 86-91.

Wayne, L. G., Brenner, D. J., Colwell, R. R. \& 9 other authors (1987). International Committee on Systematic Bacteriology. Report of the ad hoc committee on reconciliation of approaches to bacterial systematics. Int J Syst Bacteriol 37, 463-464.

Yamada, Y., Katsura, K., Kawasaki, H., Widyastuti, Y., Saono, S., Seki, T., Uchimura, T. \& Komagata, K. (2000). Asaia bororensis gen. nov., sp. nov., an unusual acetic acid bacterium in the $\alpha$ Proteobacteria. Int J Syst Evol Microbiol 50, 823-829.

Yin, G., Tao, Z., Yan, Z., Ning, W., Wang, C. \& Wang, S. (1990). Fermentation process. US Patent 4,935,359. 